\title{
Effect of curcumin on vascular endothelial growth factor in hypoxic HepG2 cells via the insulin-like growth factor 1 receptor signaling pathway
}

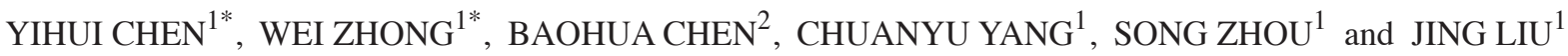 \\ ${ }^{1}$ Department of General Surgery, The 175th Hospital of PLA, Affiliated Southeast Hospital of Xiamen University, Zhangzhou, \\ Fujian 363000; ${ }^{2}$ Department of General Surgery, The 184th Hospital of PLA, Yingtan, Jiangxi 335000, P.R. China
}

Received June 29, 2017; Accepted December 8, 2017

DOI: $10.3892 /$ etm.2018.5783

\begin{abstract}
To investigate the anti-angiogenic effect and underlying molecular mechanisms of curcumin on HepG2 cells under hypoxic conditions, insulin-like growth factor 1 receptor (IGF-1R) knockout HepG2 cells were constructed using a clustered regularly interspaced short palindromic repeats/Cas9 genome-editing system. Hypoxic conditions were generated using cobalt chloride $\left(\mathrm{CoCl}_{2}\right)$. An MTT assay was performed to measure the effects of curcumin on cell viability in hypoxia-induced IGF-1R knockout HepG2 cells, while western blot analysis was used to detect the expression of IGF-1R, phosphorylated (p)-protein kinase B (Akt), p-extracellular signal-regulated kinases (Erk) $1 / 2$, hypoxia-inducible factor- $1 \alpha(\mathrm{HIF}-1 \alpha)$ and vascular endothelial growth factor (VEGF). The results revealed that $\mathrm{CoCl}_{2}$ at low concentrations (50 and $\left.100 \mu \mathrm{M}\right)$ had no significant inhibitory effects on IGF-1R knockout HepG2 cells. However, with increasing concentrations of $\mathrm{CoCl}_{2}$ and treatment time, cell viability decreased and was significantly reduced at 150, 200 and $400 \mu \mathrm{M}$ compared with the control group $(\mathrm{P}<0.05)$. The expression of HIF-1 $\alpha$ and VEGF were significantly increased when the cells were treated with 150 or $200 \mu \mathrm{M} \mathrm{CoCl}_{2}$ compared with the control $(\mathrm{P}<0.05)$. With the increase of $\mathrm{CoCl}_{2}$ concentration or the treatment time, the expression of HIF-1 $\alpha$ and VEGF were upregulated gradually. Additionally, curcumin significantly inhibited the expression of p-Akt, p-Erk1/2, HIF-1 $\alpha$ and VEGF in hypoxia-induced
\end{abstract}

Correspondence to: Dr Jing Liu, Department of General Surgery, The 175th Hospital of PLA, Affiliated Southeast Hospital of Xiamen University, 269 Zhanghua Middle Road, Zhangzhou, Fujian 363000, P.R. China

E-mail: liujdoctor@hotmail.com

${ }^{*}$ Contributed equally

Key words: curcumin, hypoxia, insulin-like growth factor 1 receptor, knockout, HepG2, hypoxia inducible factor-1 $\alpha$, vascular endothelial growth factor
IGF-1R knockout HepG2 cells. In conclusion, the findings of the present study suggest that curcumin may serve a pivotal role in tumor suppression via the inhibition of IGF-1R-mediated angiogenesis under hypoxic conditions.

\section{Introduction}

Primary liver cancer (PLC) comprises hepatocellular carcinoma (HCC), hepatoblastoma, intrahepatic cholangiocarcinoma and other rarer tumors (1). Hepatoblastoma is the most common type of primary liver tumor in children $<5$ years old (2). The incidence rate of PLC is increasing in Australia, Central Europe, the United Kingdom, Japan and North America, and this increase will likely continue due to infection with hepatitis B virus (HBV) and hepatitis C virus (HCV) (3). For patients with localized HCC, liver transplantation and resection are viable, useful treatments option (4). However, curative resection or transplantation is only possible in $30 \%$ of patients, which means that the overall survival rate of HCC remains poor (5). Transcatheter arterial chemoembolization (TACE) has been demonstrated to have survival benefits in patients with intermediate and advanced HCC and hepatoblastoma (6-8). TACE may reduce tumor burden and significantly improve the prognosis and survival of patients (6). However, TACE may also cause local hypoxia in the tumor environment, resulting in the expression of hypoxia-inducible factor- $1 \alpha$ (HIF-1 $\alpha$ ) and vascular endothelial growth factor (VEGF), which promote neovascularization (9). It is therefore necessary to study the mechanism of hypoxia-induced angiogenesis to identify novel ways of inhibiting the growth of PLC.

Curcumin [1,7-bis(4-hydroxy-3-methoxyphenyl)-1, 6-heptadiene-3,5-di-one] is a polyphenolic compound isolated from the rhizomes of Curcuma longa, which has been revealed to have anti-inflammatory, antioxidant, anti-angiogenesis and antitumor activities $(10,11)$. Curcumin has also been reported to protect the liver against the toxic effects of agents, including galactosamine (12), C-C motif chemokine 4 (13) and paracetamol (14). It has previously been reported that curcumin inhibits human breast carcinoma MCF-7 cell proliferation by inhibiting the insulin-like growth factor (IGF)-1 axis (15). Patel et al (16) demonstrated that the inclusion of curcumin to continued folinic acid, fluorouracil and oxaliplatin treatment 
reduced the survival of colon cancer cells and concurrently reduced the activation of endothelial growth factor receptor, v-erb-b2 erythroblastic leukemia viral oncogene homolog 2 (HER-2), IGF-1 receptor (IGF-1R) and protein kinase B (Akt). However, to the best of our knowledge, there has been little investigation into whether curcumin affects the angiogenesis of HCC via the IGF-1R signaling pathway.

Previous studies have revealed that IGF-1R is overexpressed in the majority of PLC tissues $(17,18)$. The interaction between IGF-1R and its ligands serves a key role in regulating the expression of VEGF $(17,19)$. Therefore, IGF-1R knockout HepG2 cells were constructed to investigate whether curcumin regulates the expression of HIF-1 $\alpha$ and VEGF via the IGF-1R signaling pathway.

\section{Materials and methods}

Cell culture and chemicals. The human hepatoblastoma cell line, HepG2, was obtained from the American Type Culture Collection (Manassas, VA, USA). IGF-1R knockout HepG2 cells were constructed and conserved within the laboratory. HepG2 cells were maintained in Dulbecco's modified Eagle's medium (DMEM; Gibco, Thermo Fisher Scientific, Inc., Waltham, MA, USA) supplemented with $10 \%$ fetal bovine serum (FBS; Gibco, Thermo Fisher Scientific, Inc.), $100 \mathrm{U} / \mathrm{ml}$ penicillin and $100 \mu \mathrm{g} / \mathrm{ml}$ streptomycin at $37^{\circ} \mathrm{C}$ in an atmosphere containing $5 \% \mathrm{CO}_{2}$. Curcumin and $\mathrm{CoCl}_{2}$ were purchased from Sigma-Aldrich (Merck KGaA, Darmstadt, Germany). Curcumin was dissolved in dimethylsulfoxide and $\mathrm{CoCl}_{2}$ was dissolved in DMEM.

Preparation of IGF-1R knockout cells. The candidate 20-base guide (g)RNA sequences were derived from the IGF-1R genome sequence (gene ID: 3480). The cDNA sequence was obtained from Han's lab (http://hanlab.xmu.edu.cn/cdna/Query.aspx, No. 25207). The clustered regularly interspaced short palindromic repeats (CRISPR)/Cas9 design tool from Zhang's lab (crispr.mit.edu/) was used to search the functional gRNA sequence (5'-GAGAACTGCACGGTGATCGAGGG-3'), which contain the downstream 3 'protospacer-adjacent motif with GG dinucleotide (N20-NGG). According to the functional gRNA sequence, a pair of oligo DNA were designed and synthesized (hIGF1R-QC-F, 5'-CACCGAGAACTGCAC GGTGATCGA-3'; hIGF1R-QC-R, 5'-AAACTCGATCAC CGTGCAGTTCTC-3'). The complementary oligo DNA were hybridized (50 ng) and then inserted to pGK1.1 (20 ng) (Genloci Biotechnologies, Inc., Jiangsu, China; http://www.genloci.com) and named pGK1.1-U6-IGF-1RgRNA. HepG2 cells were seeded in a 24 -well plate $24 \mathrm{~h}$ prior to transfection and transfected with the pGK1.1-U6-IGF-1RgRNA plasmid via the electroporation method using a Neon ${ }^{\circledR}$ Transfection system (Invitrogen; Thermo Fisher Scientific, Inc.) according to the manufacturer's protocol. Following transfection, the cells were diluted into 1096 -well plates and incubated at $37^{\circ} \mathrm{C}$ in an atmosphere containing $5 \% \mathrm{CO}_{2}$ for 2 weeks. The cells from each 96-well plate were then transferred to 48-well plates and incubated at $37^{\circ} \mathrm{C}$ in an atmosphere containing $5 \% \mathrm{CO}_{2}$ for further incubation. After cell cultures were $70 \%$ confluent, they were harvested and the genomic DNA was extracted using DNA Extraction kits (Genloci Biotechnologies,
Inc.). PCR was conducted to amplify the target region with genomic DNA derived from the cells. DNA polymerase (cat. no. R060Q; Takara, Bio, Inc., Otsu, Japan) was use for PCR. The following primer sequences were used: hIGF1R-seq-F: 5'-GTTTACCCTCTTGTCTCCCT-3' and hIGF1R-seq-R: 5'-CGGTAATGACCGTGAGCTTG-3'. PCR was performed using the following thermocycling conditions: $95^{\circ} \mathrm{C}$ for $10 \mathrm{sec}$, $60^{\circ} \mathrm{C}$ for $10 \mathrm{sec}, 72^{\circ} \mathrm{C}$ for $20 \mathrm{sec}$ for 30 cycles. Amplicons were sent to the Beijing Genomics Institute (Beijing, China) for deep sequencing.

Hypoxia and $\mathrm{CoCl}_{2}$ incubation. HepG2 cells were plated in 96 -well plates $(5,000$ cells/well) or 6 -well plates ( $3 \times 10^{5}$ cells/well) in DMEM supplemented with $10 \% \mathrm{FBS}$, $100 \mathrm{U} / \mathrm{ml}$ penicillin and $100 \mu \mathrm{g} / \mathrm{ml}$ streptomycin at $37^{\circ} \mathrm{C}$ in an atmosphere containing $5 \% \mathrm{CO}_{2}$. Following $24 \mathrm{~h}$, the medium was changed to fresh serum-free DMEM with different concentrations of $\mathrm{CoCl}_{2}(0,50,100,150,200$ and $400 \mu \mathrm{M})$ for different time periods $(1,2,4,6$ and $8 \mathrm{~h})$.

Cell survival assay. HepG2 cells were plated in a 96-well plate in $100 \mu 1$ medium at a density of 5,000 cells/well and incubated using standard culture conditions overnight. The medium was removed carefully and the purple formazan was dissolved with $150 \mu$ l dimethyl sulfoxide. Cell viability was determined by an MTT assay (Sigma-Aldrich; Merck KGaA, Darmstadt, Germany) according to the manufacturer's protocol. The optical density was determined at $570 \mathrm{~nm}$ by SpectraMax M2 (Molecular Devices, LLC, Sunnyvale, CA, USA).

Western blot analysis. Total protein was isolated from cells using a radioimmunoprecipitation buffer reagent (cat. no. P0013B, Beyotime Institute of Biotechnology, Shanghai, China). The lysates were ultrasonicated and centrifuged at $12,000 \mathrm{x} \mathrm{g}$ and at $4^{\circ} \mathrm{C}$ for $10 \mathrm{~min}$. Supernatants were collected and stored at $-70^{\circ} \mathrm{C}$. Protein concentrations were determined using a Bicinchoninic Acid Protein Assay kit (Thermo Fisher Scientific, Inc.) according to the manufacturer's protocol. Protein (50 $\mu \mathrm{g}$ per lane) was separated by $10 \%$ SDS-PAGE and electroblotted onto a nitrocellulose membrane. The membrane was blocked with Tris-buffered saline (TBS)/5\% nonfat dry milk at room temperature for $2 \mathrm{~h}$ and the membranes were subsequently incubated with primary antibodies overnight at $4^{\circ} \mathrm{C}$. Following three washes with TBS+Tween-20 (TBST), the membranes were incubated with goat polyclonal immunoglobulin $\mathrm{G}$ horseradish peroxidase-conjugated secondary antibodies (cat. no. sc-2004; 1:1,000; Santa Cruz Biotechnology, Inc., Dallas, TX, USA) for $45 \mathrm{~min}$ at room temperature. The membranes were washed with TBST three times prior to visualization using a Western Blotting Luminol Reagent (cat. no. sc-2048, Santa Cruz Biotechnology, Inc.). Image J 1.6 software (National Institutes of Health, Bethesda, MD, USA) was used to detect and analyze the relative densitometry. The primary antibodies used in the experiment were as follows: Rabbit anti-IGF-1R (cat. no. 9750), rabbit anti-HIF-1 $\alpha$ (cat. no. 3716), rabbit anti-VEGF (cat. no. 2463), rabbit anti-Akt (cat. no. 9272), rabbit anti-phosphorylated (p)-Akt (cat. no. 5012), rabbit anti-extracellular signal-regulated kinases (Erk1/2; cat. no. 4695), rabbit anti-p-Erk1/2 (cat. no. 4377) (all 1:1,000; Cell Signaling Technology, Inc., Danvers, MA, USA) 
and rabbit anti- $\beta$-actin (cat. no. sc-7210; 1:4,000; Santa Cruz Biotechnology, Inc.).

Statistical analysis. Data are presented as the mean \pm standard deviation and were analyzed using SPSS version 19.0 (IBM Corp., Armonk, NY, USA). Differences between the groups at each time point were examined for statistical significance using one-way analysis of variance and a least significant difference post-hoc comparison. The correlation between HIF-1 $\alpha$ and VEGF protein levels was evaluated statistically using Pearson's correlation coefficient analysis if the quantitative data had a normal distribution; if the data was not normally distributed, the Spearman rank correlation coefficient analysis was used. $\mathrm{P}<0.05$ was considered to indicate a statistically significant difference.

\section{Results}

Effect of hypoxia on the viability of IGF-1R knockout HepG2 cells. An IGF-1R knockout HepG2 cell line was successfully constructed using a CRISPR/Cas9 genome-editing system. To investigate the effect of hypoxia on the IGF-1R knockout HepG2 cell line, cells were treated with different concentrations of $\mathrm{CoCl}_{2}$ for $1-8 \mathrm{~h}$ and the viability was subsequently analyzed using an MTT assay. No significant differences were observed between the control cells and those treated with low $\mathrm{CoCl}_{2}$ doses (50-100 $\mu \mathrm{M}$; Fig. 1). However, the viability of IGF-1R knockout $\mathrm{HepG}_{2}$ cells was significantly reduced in the 150,200 and $400 \mu \mathrm{M} \mathrm{CoCl}_{2}$ treated groups compared with the control (no $\mathrm{CoCl}_{2}$ treatment) at the same time points $(\mathrm{P}<0.05$; Fig. 1).

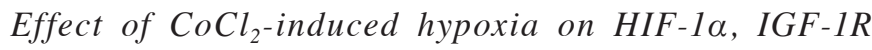
and VEGF expression in IGF-1R knockout HepG2 cells. Western blot analysis was performed to examine the effects of $\mathrm{CoCl}_{2}$-induced hypoxia on HIF-1 $\alpha$, IGF-1R and VEGF protein expression in IGF-1R knockout HepG2 cells. The cells were treated with $0,50,100,150,200$ or $400 \mu \mathrm{M} \mathrm{CoCl}_{2}$ for $6 \mathrm{~h}$ and the expression of HIF-1 $\alpha$, IGF-1R and VEGF was determined by western blotting. The protein expression of HIF-1 $\alpha$ and VEGF was significantly higher in cells treated with 150 or $200 \mu \mathrm{M} \mathrm{CoCl}_{2}$ compared with the control group $(\mathrm{P}<0.05$; Fig. $2 \mathrm{~A}$ and $\mathrm{B})$. Correlation analysis revealed that the expression of the HIF-1 $\alpha$ was positively correlated with the expression of VEGF $(r=0.85, \mathrm{P}<0.05)$ in a dose-dependent manner (data not shown).

The IGF-1R knockout $\mathrm{HepG}_{2}$ cells were treated with $150 \mu \mathrm{M} \mathrm{CoCl}_{2}$ for the indicated time periods and the protein expression of HIF-1 $\alpha$, IGF-1R and VEGF was determined by western blotting (Fig. 2C). The relative expression of each protein was calculated and it was observed that the protein expression of HIF-1 $\alpha$ and VEGF was significantly increased at 2-8 $\mathrm{h}$ compared with the control group $(\mathrm{P}<0.05$; Fig. 2D). In addition, HIF-1 $\alpha$ expression was positively correlated with the expression of VEGF $(r=0.71, \mathrm{P}<0.05)$ in a time-dependent manner (data not shown).

Effect of curcumin on IGF-1R knockout HepG2 cell viability under $\mathrm{CoCl}_{2}$-induced hypoxia. IGF-1R knockout HepG2 cells were incubated with increasing concentrations

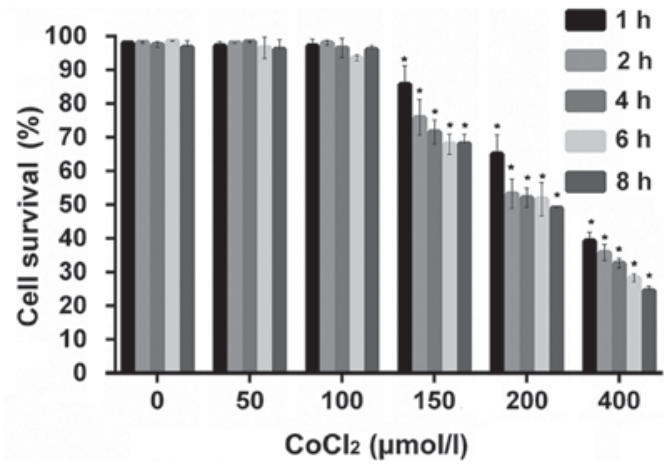

Figure 1. Effect of $\mathrm{CoCl}_{2}$-induced hypoxia on cell viability in IGF-1R knockout HepG2 cells. Cell viability was determined using an MTT assay. IGF-1R knockout HepG2 cells were treated with $0,50,100,150,200$ or $400 \mu \mathrm{M} \mathrm{CoCl}_{2}$ and incubated under standard culture conditions for 1, 2, 4, 6 and $8 \mathrm{~h} .{ }^{*} \mathrm{P}<0.05$ vs. the control group $(0 \mu \mathrm{M}) . \mathrm{CoCl}_{2}$, cobalt chloride; IGF-1R, insulin-like growth factor-1 receptor.

of curcumin $(5,10,20,30$ and $40 \mu \mathrm{M})$ in the presence of $150 \mu \mathrm{M} \mathrm{CoCl}_{2}$. It was observed that the cell survival rate decreased as the incubation time or dose increased, and all doses of curcumin caused a reduction in cell survival (Fig. 3). The incubation of cell cultures with different concentrations of curcumin at each time point $(8,12,24$ and $48 \mathrm{~h})$ had significant inhibitory effects on the survival of IGF-1R knockout HepG2 cells compared with the control group $(\mathrm{P}<0.05$; Fig. 3).

Effect of curcumin on IGF-1R, p-Akt, p-Erk1/2, HIF-1 $\alpha$ and $V E G F$ protein expression in IGF-1R knockout HepG2 cells in the presence of $\mathrm{CoCl}_{2}$. HepG2 cells and IGF-1R knockout HepG2 cells were treated with or without curcumin $(20 \mu \mathrm{M})$ under $\mathrm{CoCl}_{2}$-induced hypoxic conditions. Following $24 \mathrm{~h}$ of treatment, total cell protein was extracted and analyzed using western blotting (Fig. 4A). The expression of IGF-1R, p-Akt, p-Erk1/2, HIF-1 $\alpha$ and VEGF proteins was significantly reduced in HepG2 cells treated with curcumin compared with untreated cells $(\mathrm{P}<0.05$; Fig. 4B-F). IGF-1R knock out cells treated with curcumin also exhibited markedly reduced p-Akt, p-Erk1/2, HIF-1 $\alpha$ and VEGF protein expression compared with the IGF-1R knock out cells not treated with curcumin $(\mathrm{P}<0.05)$. Knockdown IGF-1R also inhibited the expression of HIF-1 $\alpha$, VEGF, p-Akt and p-Erk proteins in $\mathrm{CoCl}_{2}$-induced HepG2 cells $(\mathrm{P}<0.05$, Fig. 4C-F). Additionally, the difference between control group (lane A) and $\mathrm{HepG} 2$ cells with $\mathrm{CoCl}_{2}$ plus curcumin (lane B) seems greater than the difference between IGF-1R knockout $\mathrm{HepG} 2$ cells with $\mathrm{CoCl}_{2}$ (lane C) and IGF-1R knockout HepG2 cells with $\mathrm{CoCl}_{2}$ plus curcumin (lane D).

\section{Discussion}

Angiogenesis serves a crucial role in tumor growth, invasion and metastasis (20). Tumor neovascularization is a complex process that is regulated by angiogenic activators and inhibitors (20). Hypoxia is an important stimulus and key regulator of angiogenesis in cancer, and tumor hypoxia may occur due to increased metabolic activity and oxygen consumption by rapidly proliferating tumor cells (19). Hypoxia may be 

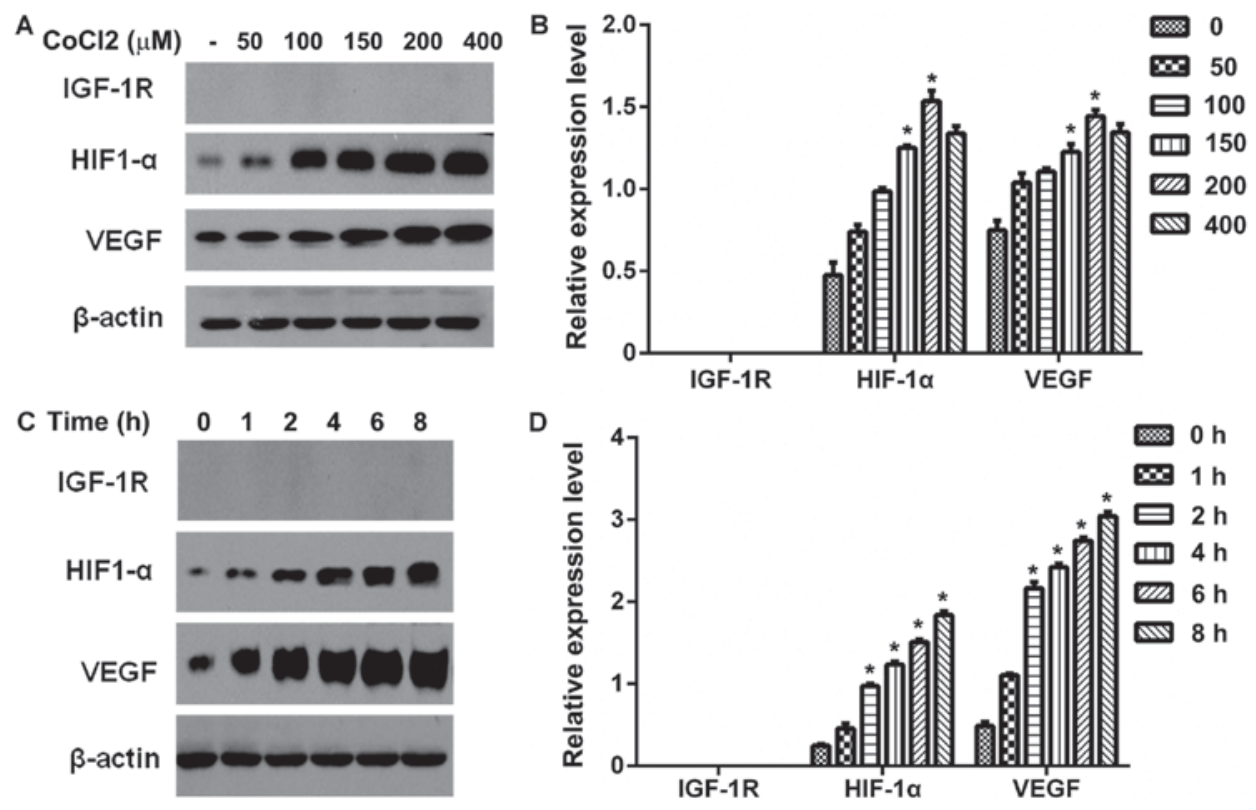

Figure 2. Effect of $\mathrm{CoCl}_{2}$-induced hypoxia on IGF-1R, HIF-1 $\alpha$ and VEGF protein expression in HepG2 cells. (A) Serum-starved IGF-1R knockout HepG2 cells were treated with different concentrations of $\mathrm{CoCl}_{2}(0,50,100,150,200$ and $400 \mu \mathrm{M})$ for $6 \mathrm{~h}$. IGF-1R, HIF-1 $\alpha$ and VEGF protein expression were detected by western blot analysis. (B) Western blot analysis data was quantified and the protein expression of IGF-1R, HIF-1 $\alpha$ and VEGF are presented as a bar graph ${ }^{*} \mathrm{P}<0.05$ vs. the control group $(0 \mathrm{uM})$. (C) Serum-starved IGF-1R knockout HepG2 cells were treated with $\mathrm{CoCl}_{2}(150 \mu \mathrm{M})$ for the indicated time $(0-8 \mathrm{~h})$. Total cell protein was extracted and IGF-1R, HIF-1 $\alpha$ and VEGF protein expression was determined by western blot analysis. (D) Graphic representation of the relative density of IGF-1R, HIF- $1 \alpha$ and VEGF protein expression levels, which were normalized to those of $\beta$-actin. "P<0.05 vs. the control group $(0 \mathrm{~h})$. IGF-1R, insulin-like growth factor-1 receptor; VEGF, vascular endothelial growth factor; $\mathrm{HIF}-1 \alpha$, hypoxia-inducible factor- $1 \alpha ; \mathrm{CoCl}_{2}, \mathrm{cobalt}_{\mathrm{t}} \mathrm{chloride}$.

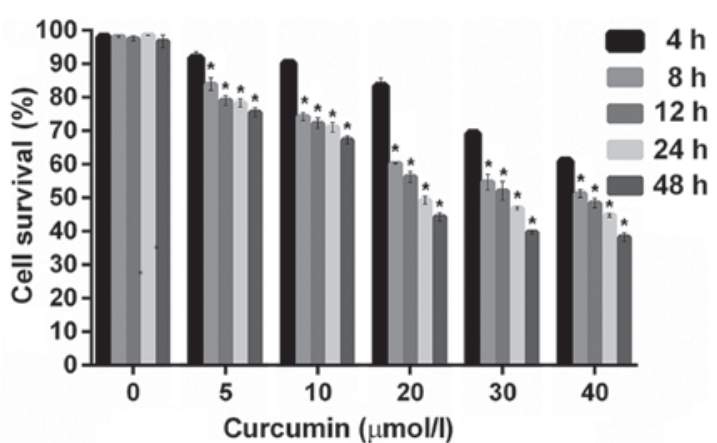

Figure 3. Effect of curcumin on IGF-1R knockout HepG2 cell viability under $\mathrm{CoCl}_{2}$-induced hypoxia. Cell viability was determined using an MTT assay. IGF-1R knockout HepG2 cells were treated with $0,5,10,20,30$ or $40 \mu \mathrm{M}$ curcumin and incubated in the presence of $150 \mu \mathrm{M} \mathrm{CoCl} 2$ for $4-48 \mathrm{~h} .{ }^{*} \mathrm{P}<0.05$ vs. the control group $(0 \mu \mathrm{M})$. $\mathrm{CoCl}_{2}$, cobalt chloride; IGF-1R, insulin-like growth factor-1 receptor.

induced by TACE, transarterial embolization, portal venous embolizations or other treatments for PLC (21).

TACE may reduce the tumor burden and improve the prognosis and survival rate of patients with PLC; however, TACE also induces hypoxic conditions, which promotes the secretion of HIF-1 $\alpha$ and VEGF and leads to tumor angiogenesis, recurrence and metastasis (8). Several previous studies have confirmed that VEGF is one of the most reliable prognostic markers of HCC (22-24). VEGF may be useful in monitoring the response to treatment in patients with $\mathrm{HCC}$ undergoing TACE, and angiogenesis in these patients may be a target for adjuvant treatments with drugs interfering with the process (25). Liapi and Geschwind (26) reviewed several anti-angiogenic agents combined with TACE for the treatment of HCC, including sorafenib, bevacizumab. Sorafenib as a complementary treatment acting on VEGF improved overall survival, time to progression and objective response rate when administrated prior to or in conjunction with TACE (27). Sorafenib was also reported to inhibit $\mathrm{CoCl}_{2}$-induced HIF-1 $\alpha$ and VEGFA expression in hepatoma cells (28). However, the incidence of adverse reactions was higher in the TACE + sorafenib group compared with the TACE only group; these adverse reactions included hepatotoxicity, hypertension and abdominal pain $(27,29)$. These results suggest that sorafenib may reduce the overexpression of VEGF when combined with TACE, although it cause liver injury. Curcumin was reported to have protective effects on the liver and anticancer effects (30), whereas its effects on angiogenesis under hypoxic conditions are poorly understood.

HIF-1 $\alpha$ is the major transcription factor specifically activated during hypoxia (19). It regulates the expression of molecules associated with glucose transport, glycolysis, erythropoiesis, iron transport and angiogenesis (31). In the present study, $\mathrm{CoCl}_{2}$ was utilized to mimic hypoxia as it enhances the stability of HIF-1 $\alpha$. It was observed that $\mathrm{CoCl}_{2}$ at a concentration of 150, 200 and $400 \mu \mathrm{M}$ suppressed the survival ability of IGF-1R knockout HepG2 cells; this effect may be due to its cytotoxicity at high concentrations. Additionally, the expression of HIF-1 $\alpha$ and VEGF was increased in a time- and dose-dependent manner and correlation analysis revealed that the expression of HIF-1 $\alpha$ was positively correlated with the expression of VEGF. These results are consistent with a previous study by the authors (32), which concluded that hypoxia induced the accumulation of IGF-1R and HIF-1 $\alpha$ and regulated the expression of VEGF in HepG2 cells. In the present study, IGF-1R knockout HepG2 cells were constructed 


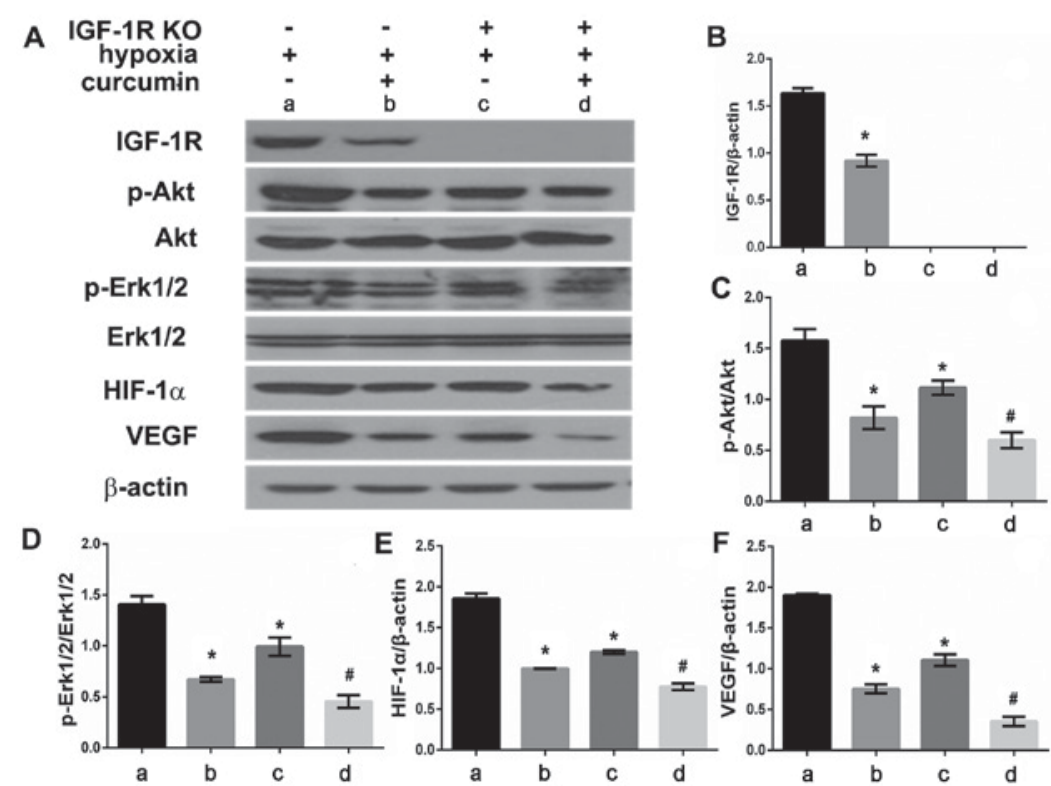

Figure 4. Effect of curcumin and hypoxia on IGF-1R, p-Akt, p-Erk1/2, HIF-1 $\alpha$, VEGF protein expression in IGF-1R knockout HepG2 cells. (A) IGF-1R, p-Akt, p-Erk1/2, HIF-1 $\alpha$, VEGF protein expression were detected by western blot analysis. Graphic representation of relative density of (B) IGF-1R, (C) p-Akt, (D) p-Erk1/2, (E) HIF-1 $\alpha$ and (F) VEGF protein levels, which were normalized to those of $\beta$-actin, Akt or Erk1/2, respectively. "P<0.05 vs. the control group (vs. group A), ${ }^{\sharp} \mathrm{P}<0.05$ vs. IGF-1R knockout $\mathrm{HepG} 2$ cells with $\mathrm{CoCl}_{2}$ treatment group (vs. group C). IGF-1R, insulin-like growth factor-1 receptor; Akt, protein kinase B; p, phosphorylated; Erk, extracellular signal-regulated kinases; VEGF, vascular endothelial growth factor; HIF-1 $\alpha$, hypoxia-inducible factor-1 $\alpha$.

and it was revealed that curcumin inhibits the IGF-1R signaling pathway under hypoxic conditions.

The IGF system has emerged as an important pathway in the development and progression of hepatoblastoma and represents a potential therapeutic target $(33,34)$. The anti-IGF-1R antibody has been reported to be effective in reducing cell proliferation and promoting apoptosis, as well as having a synergistic effect with doxorubicin (35). $\mathrm{CoCl}_{2}$ is a chemical inducer of HIF-1 and active HIF-1 induces the expression of VEGF (36). In the present study, IGF-1R knockdown inhibited the expression of HIF-1 $\alpha$, VEGF p-Akt and p-Erk proteins. Curcumin also significantly suppressed the expression of IGF-1R, HIF-1 $\alpha$, VEGF p-Akt and p-Erk proteins. The IGF-1R signaling pathway consists of IGF-1, IGF-1R and its downstream signaling targets (37). Akt and mitogen-activated protein kinase are two main downstream signaling targets of the IGF-1R signaling pathway (37). In the present study, the addition of curcumin reduced the expression of HIF-1 $\alpha$, VEGF, p-Akt and p-Erk, which indicates that curcumin may inhibit HIF-1 $\alpha$ and VEGF in an IGF-1R-independent manner. These results suggest that curcumin may suppress the expression of HIF-1 $\alpha$ and VEGF by inhibiting IGF-1R or its downstream signaling pathways (Fig. 5).

The present study was not without limitations. Firstly, $\mathrm{CoCl}_{2}$-induced hypoxia primarily depends on the regulation of HIF- $1 \alpha$ and there are HIF-independent pathways that are capable of inducing angiogenesis in response to hypoxia (38). In future studies it would be preferable to study cells under natural hypoxic conditions. Secondly, the HepG2 cell line has been reported to be misidentified; it was originally thought to be an HCC cell line but was later revealed to be derived from a hepatoblastoma cell line (39). As 90\% of PLCs are HCC, experiments on $\mathrm{HCC}$ cell lines are required to validate the results of the present study. Thirdly, intact curcumin was used in the present

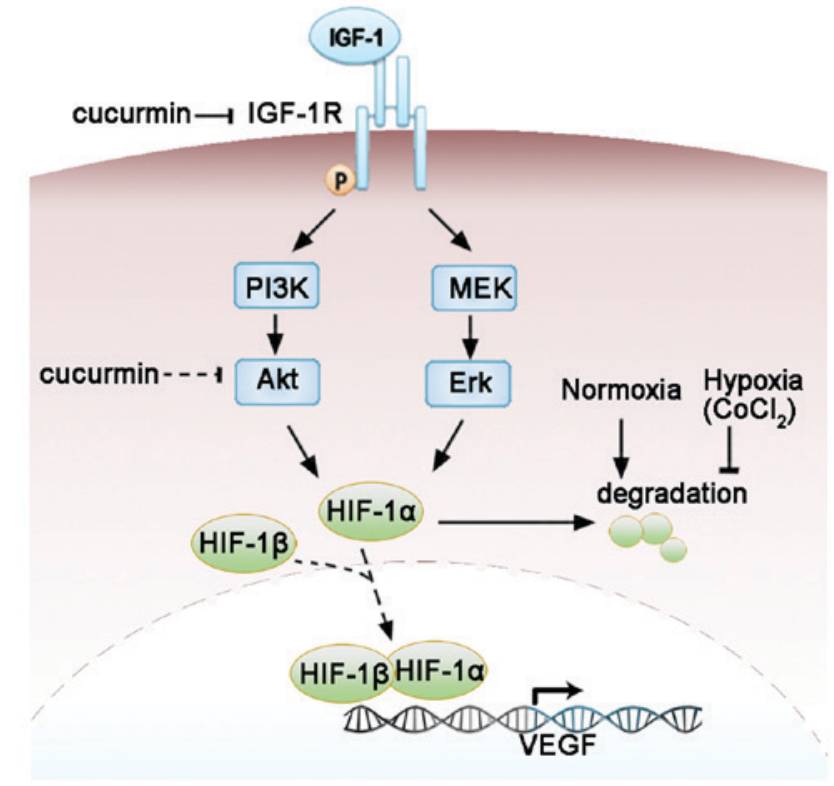

Figure 5. Molecular mechanisms by which curcumin regulates the IGF-1R signaling pathway and the expression of VEGF in HepG2 cells under $\mathrm{CoCl}_{2}$-induced hypoxia. The arrow and blocked arrow (no arrowhead) indicate stimulation and inhibition, respectively. The dotted arrow indicates the translocation of HIF- $1 \alpha$ and HIF-1 $\beta$. The dotted blocked arrow indicates the potential effects of curcumin not directly examined in the present study. It was concluded that curcumin may suppress the expression of HIF-1 and VEGF by targeting IGF-1R or its downstream signaling pathways. VEGF, vascular endothelial growth factor; HIF-1 $\alpha$, hypoxia-inducible factor- $1 \alpha$; HIF-1 $\beta$, hypoxia-inducible factor-1 $\beta$; IGF-1, insulin-like growth factor-1; IGF-1R, insulin-like growth factor-1 receptor; PI3K, phosphoinositide-3-kinase; Akt, protein kinase B; MEK, mitogen-activated protein kinase-Erk kinase; Erk, extracellular signal-regulated kinase.

cell culture study and it has been reported that, within an in vivo system, the majority of curcumin is converted to curcumin 
glucuronide, the effects of which are weaker than those of curcumin (40). Whether curcumin would have the same effects in vivo as in the cultured cells is not known. Further studies are required to investigate the effects of curcumin on the IGF-1R signaling pathway in vivo.

In conclusion, the present study provides mechanistic insights into the link between IGF-1R and VEGF that mediates angiogenesis and highlights the important anti-proliferation and anti-angiogenesis effects of curcumin. The results of the present study suggest that IGF-1R and its downstream signals may be targets for anti-angiogenesis treatment of hepatoblastomas. Curcumin in combination with TACE may be an effective treatment for liver cancer, considering its liver protective, pro-apoptosis and anti-angiogenesis effects.

\section{Acknowledgements}

This study was supported by grants from the Natural Science Foundation of Fujian Province (grant no. 2017J01164), Foundation Supporting the Army of Science and Technology of Zhangzhou (grant no. zz2016kd06) and Innovation Funds of the Medical Science and Technology of Military Region of Nanjing (grant no. 11MA082).

\section{References}

1. Bosman FT; World Health Organization and International Agency for Research on Cancer: WHO classification of tumours of the digestive system. 4th Edition. IARC Press, Lyon, 2010.

2. Sia D, Villanueva A, Friedman SL and Llovet JM: Liver cancer cell of origin, molecular class, and effects on patient prognosis. Gastroenterology 152: 745-761, 2017.

3. Bosch FX, Ribes J, Diaz M and Cleries R: Primary liver cancer: Worldwide incidence and trends. Gastroenterology 127 (5 Suppl 1): S5-S16, 2004.

4. Dageforde LA, Fowler KJ and Chapman WC: Liver transplantation for hepatocellular carcinoma: Current update on treatment and allocation. Curr Opin Organ Transplant 22: 128-134, 2017.

5. Fitamant J, Kottakis F, Benhamouche S, Tian HS, Chuvin N, Parachoniak CA, Nagle JM, Perera RM, Lapouge M, Deshpande V, et al: YAP inhibition restores hepatocyte differentiation in advanced HCC, leading to tumor regression. Cell Rep: Mar 10, 2015 (Epub ahead of print).

6. Tsurusaki M and Murakami T: Surgical and locoregional therapy of HCC: TACE. Liver Cancer 4: 165-175, 2015.

7. Sun JJ, Wang K, Zhang CZ, Guo WX, Shi J, Cong WM, Wu MC, Lau WY and Cheng SQ: Postoperative adjuvant transcatheter arterial chemoembolization after R0 hepatectomy improves outcomes of patients who have hepatocellular carcinoma with microvascular invasion. Ann Surg Oncol 23: 1344-1351, 2016.

8. Hirakawa M, Nishie A, Asayama Y, Fujita N, Ishigami K, Tajiri T, Taguchi T and Honda H: Efficacy of preoperative transcatheter arterial chemoembolization combined with systemic chemotherapy for treatment of unresectable hepatoblastoma in children. Jpn J Radiol 32: 529-536, 2014.

9. Liu K, Min XL, Peng J, Yang K, Yang L and Zhang XM: The changes of HIF-1 $\alpha$ and VEGF expression after TACE in patients with hepatocellular carcinoma. J Clin Med Res 8: 297-302, 2016

10. Jiao D, Wang J,Lu W, Tang X, Chen J, Mou H and Chen QY: Curcumin inhibited HGF-induced EMT and angiogenesis through regulating c-Met dependent PI3K/Akt/mTOR signaling pathways in lung cancer. Mol Ther Oncolytics 3: 16018, 2016.

11. Abdollahi E, Momtazi AA, Johnston TP and Sahebkar A: Therapeutic effects of curcumin in inflammatory and immune-mediated diseases: A nature-made jack-of-all-trades? J Cell Physiol 233: 830-848, 2018.

12. Zhang J, Xu L, Zhang L, Ying Z, Su W and Wang T: Curcumin attenuates D-galactosamine/lipopolysaccharide-induced liver injury and mitochondrial dysfunction in mice. J Nutr 144: $1211-1218,2014$
13. Salem MM, El-Rasheid HGA and Mahmoud AN: Therapeutic effects of curcumin and royal jelly as natural antioxidants on some biochemical parameters in hepatotoxicity induced by carbon tetrachloride (CCl4) in male albino rats. Int J 3: 520-535, 2015.

14. Li G, Chen JB, Wang C, Xu Z, Nie H, Qin XY, Chen XM and Gong Q: Curcumin protects against acetaminophen-induced apoptosis in hepatic injury. World J Gastroenterol 19: 7440-7446, 2013.

15. Mitsiades CS, Mitsiades NS, McMullan CJ, Poulaki V, Shringarpure R, Akiyama M, Hideshima T, Chauhan D, Joseph M, Libermann TA, et al: Inhibition of the insulin-like growth factor receptor-1 tyrosine kinase activity as a therapeutic strategy for multiple myeloma, other hematologic malignancies, and solid tumors. Cancer Cell 5: 221-230, 2004.

16. Patel BB, Gupta D, Elliott AA, Sengupta V, Yu Y and Majumdar AP: Curcumin targets FOLFOX-surviving colon cancer cells via inhibition of EGFRs and IGF-1R. Anticancer Res 30: 319-325, 2010.

17. Samani AA, Yakar S, LeRoith D and Brodt P: The role of the IGF system in cancer growth and metastasis: Overview and recent insights. Endocr Rev 28: 20-47, 2007.

18. El-Serag HB, Davila JA, Petersen NJ and McGlynn KA: The continuing increase in the incidence of hepatocellular carcinoma in the United States: An update. Ann Intern Med 139: 817-823, 2003.

19. Liao D and Johnson RS: Hypoxia: A key regulator of angiogenesis in cancer. Cancer Metastasis Rev 26: 281-290, 2007.

20. Nishida N, Yano H, Nishida T, Kamura T and Kojiro M: Angiogenesis in cancer. Vasc Health Risk Manag 2: 213-219, 2006.

21. Pleguezuelo M, Marelli L, Misseri M, Germani G, Calvaruso V, Xiruochakis E, Manousou P and Burroughs AK: TACE versus TAE as therapy for hepatocellular carcinoma. Expert Rev Anticancer Ther 8: 1623-1641, 2008.

22. Poon RT, Ho JW, Tong CS, Lau C, Ng IO and Fan ST: Prognostic significance of serum vascular endothelial growth factor and endostatin in patients with hepatocellular carcinoma. Br J Surg 91: 1354-1360, 2004.

23. Park YN, Kim YB, Yang KM and Park C: Increased expression of vascular endothelial growth factor and angiogenesis in the early stage of multistep hepatocarcinogenesis. Arch Pathol Lab Med 124: 1061-1065, 2000.

24. Yamaguchi R, Yano H, Iemura A, Ogasawara S, Haramaki M and Kojiro M: Expression of vascular endothelial growth factor in human hepatocellular carcinoma. Hepatology 28: 68-77, 1998.

25. Sergio A, Cristofori C, Cardin R, Pivetta G, Ragazzi R, Baldan A, GirardiL,CilloU,BurraP,GiacominA andFarinatiF:Transcatheter arterial chemoembolization (TACE) in hepatocellular carcinoma (HCC): The role of angiogenesis and invasiveness. Am J Gastroenterol 103: 914-921, 2008.

26. Liapi E and Geschwind JF: Combination of local transcatheter arterial chemoembolization and systemic anti-angiogenic therapy for unresectable hepatocellular carcinoma. Liver Cancer 1: 201-215, 2012.

27. Zhang L, Hu P, Chen $X$ and Bie P: Transarterial chemoembolization (TACE) plus sorafenib versus TACE for intermediate or advanced stage hepatocellular carcinoma: A meta-analysis. PLoS One 9: e100305, 2014.

28. Xu M, Zheng YL, Xie XY, Liang JY, Pan FS, Zheng SG and Lü MD: Sorafenib blocks the HIF-1 $\alpha$ /VEGFA pathway, inhibits tumor invasion, and induces apoptosis in hepatoma cells. DNA Cell Biol 33: 275-281, 2014.

29. Liu L, Chen H, Wang M, Zhao Y, Cai G, Qi X and Han G: Combination therapy of sorafenib and TACE for unresectable HCC: A systematic review and meta-analysis. PLoS One 9: e91124, 2014.

30. Shehzad A, Lee J and Lee YS: Curcumin in various cancers. Biofactors 39: 56-68, 2013.

31. North S, Moenner M and Bikfalvi A: Recent developments in the regulation of the angiogenic switch by cellular stress factors in tumors. Cancer Lett 218: 1-14, 2005.

32. Liu Q, Xu Z, Mao S, Chen W, Zeng R, Zhou S and Liu J: Effect of hypoxia on hypoxia inducible factor-1 $\alpha$, insulin-like growth factor I and vascular endothelial growth factor expression in hepatocellular carcinoma HepG2 cells. Oncol Lett 9: 1142-1148, 2015.

33. Gray SG, Eriksson T, Ekström C, Holm S, von Schweinitz D, Kogner P, Sandstedt B, Pietsch T and Ekström TJ: Altered expression of members of the IGF-axis in hepatoblastomas. Br J Cancer 82: 1561-1567, 2000. 
34. Tomizawa M and Saisho H: Signaling pathway of insulin-like growth factor-II as a target of molecular therapy for hepatoblastoma. World J Gastroenterol 12: 6531-6535, 2006.

35. Yue L, Wang Y, Wang H, Gao H, Liang J, Sui A, Xiang J, Zhou F, Xu C, Zhao W, et al: Inhibition of hepatocellular carcinoma cell growth by an anti-insulin-like growth factor-I receptor monoclonal antibody. Oncol Rep 28: 1453-1460, 2012.

36. Rey S and Semenza GL: Hypoxia-inducible factor-1-dependent mechanisms of vascularization and vascular remodelling. Cardiovasc Res 86: 236-242, 2010.

37. Simpson A, Petnga W, Macaulay VM, Weyer-Czernilofsky U and Bogenrieder T: Insulin-like growth factor (IGF) pathway targeting in cancer: Role of the IGF Axis and opportunities for future combination studies. Target Oncol 12: 571-597, 2017.

38. Arany Z, Foo SY, Ma Y, Ruas JL, Bommi-Reddy A, Girnun G, Cooper M, Laznik D, Chinsomboon J, Rangwala SM, et al: HIF-independent regulation of VEGF and angiogenesis by the transcriptional coactivator PGC-1alpha. Nature 451: 1008-1012, 2008 .
39. López-Terrada D, Cheung SW, Finegold MJ and Knowles BB: Hep G2 is a hepatoblastoma-derived cell line. Hum Pathol 40: $1512-1515,2009$.

40. Shoji M, Nakagawa K, Watanabe A, Tsuduki T, Yamada T, Kuwahara S, Kimura F and Miyazawa T: Comparison of the effects of curcumin and curcumin glucuronide in human hepatocellular carcinoma HepG2 cells. Food Chem 151: 126-132, 2014.

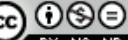

\section{This work is licensed under a Creative Common Attribution-NonCommercial-NoDerivatives 4.0 International (CC BY-NC-ND 4.0) License.}

